\title{
Energy consulting services in the information age - literature review
}

Are E. Kjeang ${ }^{1 *}$, G. Venkatesh', Magnus Ståhl ${ }^{1}$ and Jenny Palm²

\begin{abstract}
The institution of energy consulting services is one of the several government instruments for improving the efficiency of energy usage in many European countries. Various forms of advice on energy issues are offered to households. In Sweden, there has been a drop in the number of households who avail of this service, even though it is offered independently, free of charge and easily accessible. Instead, Swedes have been increasingly seeking information on the Internet (websites, blogs and social media), which can be seen as both a challenge and an opportunity for the energy consulting service offered by Swedish municipalities. The aim of the literature study is to present an overview of current research in the area of energy consulting targeting households. This to identify central themes in the research front, identify knowledge gaps and discuss which challenges previous research emphasise for energy consulting services targeting households. The results show that research indicates that a measurement-feedback-communication strategy for households is necessary if one wishes to effect a change in consumer behaviour. Today, consumers expect more individualised information than before. Here, the three dimensions of sustainable development can be useful. Energy consulting is also better appreciated if it occurs in situ -at the customer's home. How it can and should be developed in an increasingly digitalised world is a topic we think is vital for future research. Also, with sustainable development becoming increasingly important in this century, an interdisciplinary approach to energy consulting is strongly recommended by the authors of this paper.
\end{abstract}

Keywords: Communication, Behaviour, Internet, Households, Energy consulting

\section{Introduction}

How the developed countries of the world modify, manage and maintain their energy supply systems will have a bearing on climate change, and also influence the success of efforts made, in moving along the path of sustainable development. If we narrow down the focus to Sweden, we note that energy usage in buildings-for space heating, water heating and electricity-accounts for about $40 \%$ of Sweden's total energy usage annually [1]. This means that a reduction of $5-10 \%$ can considerably curb the energy sector's environmental impact. Presently, there is a consensus in the EU and their expert panels that energy efficiency improvement is the most profitable and the simplest way to achieve the overriding goals [2]. At the same time, energy efficiency is the one 20-20-20 goal that Sweden seems to not be able to reach [3], which indicates

\footnotetext{
* Correspondence: are.kjeang@kau.se

${ }^{1}$ Department of Engineering and Chemical Sciences, Karlstad University, Karlstad, Sweden

Full list of author information is available at the end of the article
}

that an efficient energy consulting might be one of the several important policy instruments to develop in the struggle for improved energy efficiency in society.

For more than 35 years, energy consulting has been offered within the building stock in Sweden, especially the single-family house sector. At present, the service is available to the public in most municipalities, from energy and climate advisers (consultants). The service is financed by the Swedish Energy Agency, which is also responsible for instructing and training the energy and climate consulting teams. The municipal energy and climate consultants are assigned the task of disseminating locally and regionally adapted knowledge about and insights into energy efficiency improvement, energy usage and environmental impacts. The local consultant (adviser) is normally a man/woman with an engineering degree in construction or energy engineering. Some of them do have longstanding work experience from the building sector. It must be mentioned though that of late, more women with degrees in environmental science 
are hired as energy and climate advisers. In 2012, 78\% of the 200 advisers had a university education and $38 \%$ of them were women [4].

Energy and climate consulting is one of the several governmental policy instruments in the domain of the environment. The others are legislation, taxation, grants, education and other modes of information dissemination. The entities responsible for energy consulting are the municipalities or other regional bodies, and this service is provided to municipal residents and small enterprises. In addition to the local service, there are 15 regional energy offices, which are responsible for administering the EU's energy policies. The title-energy adviser or consultant-can also be found at major energy companies and in consultancies in the service sector.

The municipal energy consulting services in Sweden have for some years impaired by relatively basic inadequacies such as vagueness of the goals set for them $[4,5]$. In different surveys carried out in the late 2000, Mahapatra et al. have studied the perceptions of both the energy advisers themselves and the homeowners on how the local energy advice activities are working $[5,6]$. The number of people availing these services is also declining, according to SCB-Statistics Sweden [7]. In July 2016, a new regulation was adopted [8], and from 2017 onwards, larger municipalities in Sweden will obtain more funding and there will be able to hire a team of advisers. At the same time, some smaller municipalities will discontinue their advising service, while others have to cooperate with neighbouring municipalities to keep up the service function. The owners of single-family houses, who traditionally have been the major target group, increasingly use the Internet to look for and obtain information in the realm of energy use and, in the process, end up relying on sources, the quality of which is difficult to assess ('Internet' in this paper should be understood as websites, blogs and social media). In all likelihood, the Internet will become even more dominant in the years to come.

It would be obvious then to choose to replace the expensive personal advice offered today on various issues with a robust website. The Swedish Consumer Agency presented 'Hallå konsument!' (Hello consumer!) in 2015, which included an investment in a new website that is expected to develop and rationalise its operations. For information, in a broad sense, a website may work beautifully since it gives the opportunity to display photos and video clips to demonstrate written instructions and recommendations on a multitude of issues. One or several website forums can also give committed and knowledgeable people an opportunity to disseminate information about functioning good ideas, as well as completely new ones which may be tested. A lively forum can increase local engagement in the issues while rapidly spreading news about experiences of households.
As alluded to earlier, information sought on the Internet, has its advantages and disadvantages. A disadvantage is that well-founded expert advice gets obfuscated by the appealing visuals and the catchphrases used. When it comes to houses, both technical changes and modifications in the patterns of use of the rooms, can pose challenges to the physical construction as well as the indoor climate (humidity, temperature, air flow etc.). Energy efficiency improvements in existing single-family houses influences and is influenced by several lifestyle aspects like the use of lighting, appliances, heat pumps and climate shells. Measures to improve the climate shell and efforts involving ventilation are the areas in which house owners are considered to be in need of expert advice. The indoor environment in many singlefamily houses is flawed. Both material usage (flooring for instance) and poor air circulation affect the indoor environment [9]. The change of heating systems-type and capacity-which has become quite common in Sweden during the last decade, also impacts the indoor climate. Several homes in Sweden, which are used to be heated by oil or wood in the past, have switched to alternatives, like district heating or heat pumps (geothermal). Often, information on what happens in an old house when the chimney is no longer in use is missing or neglected. Knowledge about how the problems can be avoided technically has not filtered down to the house owners.

Additional insulation of the attic, outer wall or basement walls (the so-called climate shell) combined with window replacements have a durable effect which reduces the energy usage over a long period of time. However, these insulation measures always entail the risk of dampness and mould formation on the construction elements. This is nothing new...it was a part of energy consulting manual, back in the 1980s [10]. However, owing to the large-scale changes in the types of heating systems used, challenges have mounted. Using energy optimally in Swedish single-family households has a strong environmental and economic rationale. Does the trend that more and more house owners consult the Internet pose a risk, in the form of the indoor environments of many houses deteriorating?

The aim of this paper is to compile current research in the area of energy consulting (advising) targeting households. This with the purpose to identify central themes in the research front identifies knowledge gaps and discusses which challenges previous studies emphasise for energy consulting services targeting households. Another purpose is to look for sustainability perspective in this literature.

\section{Literature review}

Focus for the literature review is three broad central themes in relation to energy consulting: energy advice, 
the Internet as a medium of information, and communication. The last theme-communication-primarily involves energy consulting in relation to household decisionmaking process concerning energy efficiency or investment in, for example, a heating system. As mentioned in the 'Introduction' section, our interest concerns how energy consulting will develop in relation to an increased use by the households of Internet when finding information. The three themes chosen for the literature review are central for understanding the impact of a widespread use of Internet for energy consulting.

\section{Method}

A broad and systematic literature review was conducted. The search engines used were OneSearch and Google Scholar. The subject databases used were InSpec, ByggDok and the database ScienceDirect.

The search words used were energy advice, energy advicing, energy behaviour, households, energy saving, energy saving in buildings, user behaviour, review energy advice, energy conservation, banking online, Internet banking, and In some cases truncation was used (e.g. energ*).

The total number of relevant publications found were 65. All publications were read through, and a selection was made from the results obtained hereby. Articles focusing on energy saving in buildings per se were kept out, unless it turned out that aspects of advising/information/household experiences were a part of those articles. Some articles which intention mainly was to develop knowledge in relation to socio-psychological aspects rather than energy consulting were also kept out of the study. Below, we are presenting the most relevant findings in relation to our aim to identify the research front on energy consulting especially focusing on what challenges are identified in relation to an increased use of Internet for information seeking.

\section{Energy advice}

There are relatively few articles in earlier research, specifically highlighting energy consulting services. Many researchers (most of them European) however have studied energy use reduction approaches and attempts made to influence households by providing information. The bridge between information and advising is, in many cases, flexible.

The British researcher Sarah Darby has, in a study in 1999, summarised different energy programmes and related activities introduced in Great Britain in 19851997 and added her own questionnaire and interviews, the latter conducted with more than 100 'advisers', many of whom were working as installation engineers. Darby also compares her observations with experiences made in Sweden, Norway and Finland. Her conclusions include the finding that low-income households are in the greatest need of help, not least of the simplest tips on how to reduce energy usage. Darby notes that building trust is facilitated by a local connection and that personal advice is most beneficial, not least when the consultation takes place in the home. Having broad technical skills is not enough; communication skills are essential [11].

Similar conclusions are drawn in several Swedish analyses [5, 12, 13]. As far as the skillsets required are concerned, comparisons can be made with other social activities where advice is offered and where there is an ambition to be independent of economic or branch interests. This is the model in Swedish agriculture, for instance, where the Rural Economy and Agricultural Societies offer advice. In the case studies conducted in the agricultural sector, the importance of advisers with a natural science background as well as communicative skills is emphasised [14].

Advising on energy issues often involves buildings and, specifically, residential buildings. Technical issues therefore dominate, for example, how to heat the building, how to choose the right appliances and how to improve the climate shell. The final energy usage will be determined by the behavioural patterns of the residents and other people-visitors, maintenance personnel, and etc.-who use the facilities/services in the building. Several researchers see a need for more customised proposals for different types of households $[15,16]$. This is confirmed by Palm [17] who has conducted interviews with Swedish households and observed their dissatisfaction with energy advisers who, when in direct contact with the householders, fail to question and discuss their benavioural patterns which may perhaps be having a great bearing on the energy usage within the households. Palm remarks that households need clarification on what can be regarded as 'private issues' too (such as what a reasonable indoor temperature is or how long to shower), not only which appliances to buy. This, according to her, would provide a better basis for the households to make reflective decisions.

When individuals are renovating their houses, or building new ones, energy issues such as heating systems and the quality in the climate shell are on the agenda. The need for help to sort out all issues is great, but the stressful situation, which results when many decisions are to be made in a very short span of time, results in the decision-making being handed over to the builders and energy companies [18]. The report implies a dissatisfaction with the fact that energy advisers, who are supposed to be independent, fail to guide the house owners adequately in making the right choices. This shortcoming in responding to customer needs was also noted in an extensive survey of energy advising in Sweden, conducted in 2013, and commissioned by the Swedish Energy Agency [4]. 
In more recent times, energy usage measuring 'in-home displays' and different types of feedback to households have been studied, not least in Europe. The largest follow-up is, however, American, involving 600,000 households across the continent which were given the opportunity to get regular feedback on their energy usage and suggestions for improvement and comparisons with other households in the neighbourhood. On an average, the cuts were estimated at 2\% [19]. Among the European studies treating the corresponding theme, there are English, Swedish and German contributions. The permanence of household engagement, however, is often low [20, 21]. In a minor follow-up interview series, researchers noted that energy awareness was on the rise in households. Some households were even frustrated that they were not able to do more and both the market and the authorities did not offer any guidance [22]. In England, there is currently a largescale project replacing electricity meters (and gas meters) and installing 'in-home displays'. Researchers like Buchanan et al. [23] have questioned the economic rationale behind committing investments to installing such meters and in-home displays. These researchers have argued that there is inconclusive proof about the positive effects of such installations, when it comes to energy use reduction in households.

The practice of keeping a log of household energy usage has been tested in a Swedish study. The members of a household kept individual logs on energy-related activities during $24 \mathrm{~h}$, a procedure which can yield knowledge of household patterns of habit and direct feedback on changes [24].

Recurring feedback via e-mail communication every week increased women's interest in household saving efforts [25]. The different reactions between men and women to advice on energy use reduction were noted in a study which included the interviews of Swedish households. The women appreciated a slightly higher indoor temperature and taking a bath more than men [26]. The researchers also noted that new habits can last when the advice is easy to understand and simple to apply and, in additon, saves money. The study also tested household reactions to electricity time tariffs, with cheaper electricity at nighttime and during weekends. Women, not least in families with small children, experienced stress in adapting household laundry time to the tariff [26].

New EU directives place demands on the energy companies to contribute to a more efficient energy usage among their customers. Some companies have addressed this need earlier, but in connection with the deregulation of the electricity market, the interest has waned [27]. The new approach has led to difficulties in cooperation among the companies' organisations and also to distrust among their customers [27]. Energy tariffs give very little motivation for reduction in usage, and the invoices are often incomprehensible. The tariff should reflect usage without confusing fixed elements in order to encourage household changes in behaviour [28]. Researchers suggest that this would make it easier for everyone to obtain feedback on measures undertaken. This is particularly important to low-income households, which cannot invest in expensive measure for improvement.

Other methods adopted are engaging people at the local community level [29]. A study conducted in Bulgaria and Croatia divided the consumers into two groups: 'energy citizens' and 'energy consumers' [30]. A recently conducted Finnish action research study tested both a target- and usage-oriented information campaign and a more long-term supporting information one, focusing on expensive reconstruction measures [16]. The authors emphasise the importance of personal contact for the households in the interactive process. In the course of the study, the researchers could also sense the emergence of several new business opportunities.

When consumers get advice on behaviour issues, is energy use always optimised? The answer is no, as shown by a study based on three households which were offered technical advice on the maintenance of their heating systems [31]. Different 'mental models' held by the participants determine the effectiveness of the advice offered.

\section{Internet as a medium of information}

The Internet, needless to say, has spawned a cultural revolution. This may be a cliché, but in a very short time, the 'library', which was a physical structure one had to travel to, is now also available on one's computer, tablet or smartphone. It is much easier to get information very quickly. This applies to virtually everyone even though households in rural areas may not have an Internet connection. Marwan M. Kraidy was one of several researchers who understood the advantages that could be harnessed from the Internet. He writes about this democratic tool in a true sustainable development spirit where the local can be part of the global [32] and observes that theories on mass communication must be revised. He also warns that accessibility can be a new dividing line between 'us and them', perhaps a new North-South divide.

Sweden lists high in the world, when it comes to accessibility to and use of the Internet [33]. South Korea, however, has a faster Internet than Sweden on date. With regard to the proportion of the population having access to the Internet, Sweden ranks second, next to its western neighbour Norway [34]. It follows that in Sweden, important information can be communicated to most of the citizens very quickly. The banks were quick to latch on to the rationalisation possibilities offered by 
the Internet. Simple bank services could be transferred to the customer, and the number of employees could be reduced. The Internet bank is taken for granted in the Scandinavian countries, while the mid-European countries have a smaller share of Internet bank customers [35]. The share drops further in southern Europe (some countries registering just 10\%). In several developing countries, the percentage is even lower. The banks work in different ways with 'social activities' to raise customer trust in the safety of the Internet bank and to convince them of the advantages [36]. Apparently, many customers still appreciate the one-to-one contact with a bank officer. Personal contact lends comfort, and the bank visit is a part of daily life.

A related issue is if the Internet in a wide sense can help promote interest in energy issues and ultimately lead to energy use reduction measures in one's household. In the preceding section, examples of how energy companies could communicate with customers in a simpler way were presented, which often has a favourable result in terms of reduced energy usage too.

In the report 'Energirådgivning 2.0' (Energy consulting 2.0), Westelius analysed the potential of the Swedish energy consulting services to utilise the Internet. When Westelius wrote his report, the services were relatively less affected by the Internet. He found that the older model of 'energy counselling' with one-way expert advising prevailed [37]. Presently, the situation is different and advisers have, for example, considerably fewer phone contacts. According to SCB, Swedish households often start their searches for information on the Internet when energy issues arise [7]. As far as looking for information online is concerned, it must be pointed out that the older the website, the greater is the possibility that it appears earlier in the list of matches shown when one does a search on Google for instance. In addition to the age of the website, the number and quality of links to and from the website is also a determining factor [38]. Thus, it does not really mean that older websites with more high-quality links to it from other websites necessarily carry reliable and updated information which energy users in households would find useful. On the World Wide Web, unfortunately, popularity does not automatically imply reliability and usefulness. Energy users keen on obtaining information online often lack the patience to browse many websites one after the other and thereafter consult human experts (energy advisers in other words) about their findings.

Westelius sees great opportunities for a more effective information channel to households through the Internet, which is an interactive channel, capable of being a forum for sharing experiences or professional expertise. $\mathrm{He}$ refers to the American 'word-of-mouth' research. Studies show that consumers tend to have greater trust in the oral advice of fellow human beings in different contexts. Expertise is not requested until expensive and technically complex systems are to be bought. In the human exchange of experience, the blog can also probably work as a means of communicating one's personal experiences with readers [37].

Westelius also emphasised energy consulting services as an unexpectedly effective way of conveying expertise. Now, 8 years after Westelius wrote this, the Internet provides a completely new channel of information to the average Swede. For some years, a notable trend in the healthcare sector has been this: Well-informed patients and visitors display a sceptical attitude towards what the healthcare personnel say/advise/recommend. Recently, the Swedish Radio focused on some serious health problems which prevail among Swedish children. These children, who despite getting healthcare recommendations from personnel in hospitals and clinics, were on the same deficient low-carb, high-fat (LCHF) diet, as their parents [39]. An urgent issue is therefore to understand how people understand and use information which is provided to them (or which they seek and find), without understanding the varying degrees of reliability of information from different sources.

The Swedish governmental initiative Bygga-Bo-Dialogen (Building-and-Living Dialogue) is mentioned as one of the nine 'good examples' of energy-related attempts to improve the information and/or the content of energy consulting. For a long time, local meeting places have been created for building companies, municipalities, regional and national public agencies. The use of interactive communication benefits the positive learning process and contributes to the ambitions of the people involved to cooperate in the spirit of sustainable development [40].

\section{Communication}

In 1992, Stern claimed that 'money is not the only important motive for conservation'. He was engaged in compiling research in psychology on how households acted in terms of energy usage in the 1970s and 1980s. Stern argued that these experiences should be used in the future energy efficiency improvement programmes [41]. In the study 'Saving electricity—-for the money or the environment', three psychologists give over 2000 electricity customers in Germany (Dortmund) saving tips linked to cost saving as well as reduction of carbon emission [42]. The result was that the environmental link gave a better result and also had greater repercussions when other energy-based household activities such as transportation and food were tested.

There are a number of fundamental explanatory communication models. Cialdini challenges our view of ourselves as rational and wise creatures when he reminds us of our origin and its effect on human reactions, position 
taking and habit making [43]. Much is inherited from a different time when intuitive and quick decisions decided whether one would live to walk another day. Our brain seems to be working in the same way today as in the Stone Age, despite all the evolution that has happened over time. We seek the support of the 'group', just as early Homo sapiens did in the distant past. This may be manifested in signalling our belonging such as wearing the pink badge or an ice hockey club scarf.

Changing habits or behaviour can imply making sacrifices and thereby could take a long time to be effective and manifest. Former smokers know about this. Malcolm Gladwell discerns a three-point road towards change, which he calls 'the tipping point'. Gladwell claims that we must be susceptible to information. If we are told that we suffer from a serious disease, for instance, the message will not get across unless we are in the right and relaxed mood [44].

Steg [45] compiled the existing research at that time in relation to how to promote household energy conservation, with special focus on psychological literature. She stated that most studies carried out had followed a monodisciplinary approach and thereby provided only a limited view, as they considered only a selective set of factors influencing energy use. Some years later, Steg and collegues did a questionnaire survey in which a selection of the population in the Netherlands responded to questions on their environmental commitment. The conclusion was that people with a strong environmentfriendly identity do not need any prodding or encouragement when it comes to undertaking measures in the interest of the environment [46]. Earlier research also indicate that if this personal identity is strengthened in society, it will be a cost-efficient way of moving towards an eco-friendly future. A study of 400 German households showed that the environmental arguments are important when change of heating system is discussed, but less so in the case of insulation measures [47].

In a report to the American Climate Policy Initiative (CPI), German experiences of information channels supporting renovation processes in existing residential buildings, aiming to reduce energy usage, are described. The data were collected by seven German researchers and then supplemented with similar data from other countries, primarily Great Britain, Finland and Sweden. In an attachment, there are nine 'case studies', good examples, among others, the Bygga-Bo-Dialogen and the Swedish Energy Consultant Services [40]. On the basis of the literature, the researchers define three categories of information tools: The first one concerns awakening interest via the energy bill, 'in-home-displays' and etc. The second tool helps owners to plan and economise since experience shows that experts are trusted but the cost is difficult to bear for the owners who instead rely on finding information on the Internet. Energy tax credits can be a useful tool. However, the third tool involves informational and educational measures and possible certifications of craftsmen and installation engineers. In conclusion, the researchers suggest that the information tools require consideration of legal, technical and cultural factors [40]. Among the cultural factors to be considered today, the likeliest one is the demand for target group customised information as well as a sense of individual adaption [15].

\section{Discussion}

There are several interesting reflections that can be made from the literature review presented here in relation to the three pillars of sustainable development, as presented in the Brundtland Commission report [48]. This is illustrated in Fig. 1. Still, there is a distinct absence of publications handling the business of energy consulting from a sustainability (triple bottom line) perspective.

Traditionally, energy advising has been strongly associated with and driven by economic considerations. Energy usage was, and primarily is, an operational expense. If a technical or behavioural measure is to be undertaken, the house owner/family would like an attractive return on their investment. Socially, there was a relatively strong commitment in the 1980s that Sweden should get rid of its dependency on oil. Oil was expensive as well as detrimental to the environment. Later, in the 1980s and 1990s, the environmental aspect was added. The arguments for taking precaution to at least slow down climate change became stronger. But what is the situation today? The environment and climate issues need to be urgently addressed. At the same time, the Swedes and other Westerners are growing tired of the

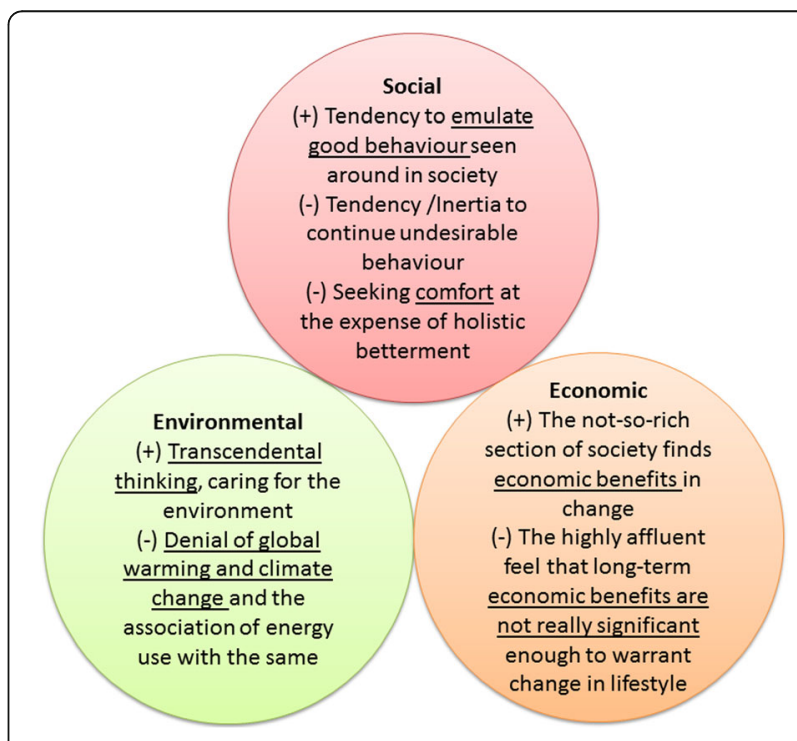

Fig. 1 Human behaviour in the context of household energy usage issues in relations to the three aspects of sustainable development 
climate change issue [49], but the awareness is high, and many relieve their consciences by choosing to commute by bus instead of car and replace the oil heater with district heating. So, the picture is multifaceted.

But let us look at earlier research on energy consulting in relation to the three dimensions of sustainability.

\section{Economic aspect}

'To measure is to know' is an old saying in the 'energy optimising' domain. This became topical when new house owners in Sweden contacted energy consultants in the 1980s, as they were concerned about the outgo on their electricity bills. As to former tenants living in a flat with heating and hot water included in the rent, it is often difficult for them to come to terms with the responsibility of paying up for the household's real and measured energy usage. The advice to read the electricity meter regularly and find out where the energy was used was often an effective recommendation.

Recent research has also paid attention to getting responses with thorough feedback on different types of energy usage. Recurring feedback through e-mail, for instance, with new suggestions and ideas is necessary for sustaining the interest. Expectations of quick reductions in energy usage may be unrealistic, and user-friendliness can and should be developed in this regard. Presently, a mobile application is an attractive possibility. Both knowledge and interest can be generated through easily accessible statistics and control opportunities. When measures are taken, response in the form of reduced energy usage and energy costs can be immediate and this will also strengthen the motivation to continue along the same path. People often lack the patience and the consistency to sustain the measures they undertake to improve the efficiency of energy use in their homes. They need to be told if they are succeeding in what they are doing and if they could do things a little bit differently. For this, what is necessary is a communication strategy, whereby for example the energy adviser could interact with them on a weekly basis or on a monthly basis with a follow-up advice. It is also likely that this interest may 'spill over' into the areas of food and transportation, thus covering the overall environmental impact of the household.

\section{Environmental aspect}

Energy consulting has during the years gone from emphasising economy efficiency to combine an economy perspective with that the same measure is also beneficial for the environment. Economy or the environment-which is the main reason for being concerned about energy usage in a family house? The answer could be comfort. Traditionally, the Swedish ranking of reasons in the area of energy efficiency improvement and saving would be as follows: (1) economy, (2) comfort and (3) the environment. Often, the truth is that all three parts are included in the argumentation, but the private economic benefit has been a cornerstone for engagement when it comes to undertaking measures to reduce energy usage in houses. In German and Dutch studies, the 'environment argument' is stronger. There are probably reasons to question the results. Several Swedish studies show that people tend to say that they do a lot more for the environment than they actually do. On the other hand, the mentality might be different in Germany and the Netherlands. In Germany, for instance, the major Energiwende project is in progress and has a broad national acceptance, according to a national survey made for BDEW, German Association of Energy and Water Industries [50].

The equality theme: When energy advisers met with a house owner in the 1980s, it was usually a man. Energy was a technical matter with some economic aspects and therefore seen as a man's domain at that time. Now it is different, which is obvious in several of the articles referred to. For example, women's interest in the British study increased when the feedback was frequent after the installation of meters/displays. The women showed great engagement in Karlstad also when the municipality ran the project Everyday Environment 10 years ago, when families were advised for a long time in their 'green transition'. Is it possible that the opportunity to control heating systems and electrical appliances via a mobile application can boost engagement further?

\section{Social aspect}

In earlier research on energy consulting, the social aspect is surprisingly missing. It is however possible to see the social relevance of the studies even if the authors themselves are not referring to their finding in these terms. One such issue is if providing advice to households in situ is the best approach or is it irrelevant to the effectiveness of the advice provided. In the British evaluation by Darby [11], in situ consulting was favoured. The first author's (Are Kjeang's) energy consulting experiences in the 1980s support this statement made by Darby. Considering the superiority of home visits for providing energy advice, over opting for other approaches to do so, in the light of Gladwell's theories, it is reasonable to assume that house owners (or farmers) are in the right mood to be susceptible to information and advice at home. Other advantages are that several members of the household can participate, the adviser can observe and make the house owner understand specific technical details or problems in his/her house and the adviser also has a chance to get an impression on how the house is used. In Denmark, a full-scale 'advice at home' is now in progress; it is termed BedreBolig 
(better houses), where specially trained consultants, for a fee, are trying to make Danish house owners take energy-saving measures when the houses undergo renovation. A problem is the unwillingness to pay for the consulting services. Another complication is to convey a technical message in an understandable way. Some studies indicate that it is difficult for house owners/residents to understand how the heating system works. This can be a minor hurdle with in situ consulting.

Can a 'super website' fulfil all the needs coming with the different dimensions of sustainability? A well-structured website for energy advising in Sweden could be an alternative or a complement to the personal component. Today, every municipality has its own website with energy advice, activities and various links. Westelius' ideas and suggestions on energy Wikipedia and energy forum, which are parts of an Internet-adapted energy advising strategy, are interesting. Ten years ago, such a website might have solved most problems for someone trawling the Internet for information. Today, it is also a matter of meeting the young people and new house owners who are moderately interested in energy issues and now and then can benefit from good advice. This calls for a presence on the social media.

The banks were quick to avail of the advantages of the Internet. Studies show that many bank customers, especially in southern Europe and poor countries in the world, are not eager to abandon the old way of carrying out their bank errands. Why are people sceptical and in what situations does the Internet bank fail to satisfy them? Could the reason be that when one is discussing about applying for a loan, one wishes to see and talk with an adviser? Follow-up questions are part of a conversation and the customer wants to ask these questions directly. The bank's representative probably also wants to meet the customer for a loan negotiation. Can a Skype conversation replace a face-to-face meeting?

Another important issue to consider both in research and in practice is if the distrust of experts are increasing? Swedish studies show that when house owners choose heating solutions, neighbours and friends play a great role as 'experts'. This is probably a relatively widespread phenomenon in Sweden, and it migh be that the Internet has contributed to this distrust. On the Internet, people can present themselves as experts and also rightfully so, at least in relation to measures tried out in their own homes and to how they live their daily lives. The reporter in a radio programme [39] asked the following question: "Why do you think that parents of diabetic children listen more to advice that is not scientifically proven?' 'The chief physician Gun Forsander at Drottning Silvias hospital for children answered: It is difficult to say. Sometimes it seems that what's on the Internet has more impact than what we try to convey at the diabetic clinics. It could be a desire to rebel against whatever the research community holds as truths'.

\section{Conclusions and recommendations}

The literature review shows that research indicates that a measurement-feedback-communication strategy for households is necessary if one wishes to effect a change in consumer behaviour. More individualised information than before is expected by consumers. Energy consulting is also better appreciated if it occurs in situ-at the customer's home.

The review indicates a need for researching further into the possibilities of testing/developing methods to get more households to choose to implement technical as well as behavioural changes to reduce their energy usage. There is also a distinct absence of publications discussing energy consulting from a triple bottom line/sustainability perspective. As indicated earlier in this paper, the imperativeness of an interdisciplinary approach has also been emphasised by Steg [45]. While the Internet is here to stay, the question to be asked is: How can Internet-based consulting work synergistically with personal consultation so that knowledge can be used as an effective tool to supplant prevalent general opinions (which may be in great need of being corrected/changed), and inculcate good energy usage practices in the minds of people?

These can form the bedrock of further research in this area.

\section{Funding}

The research was funded by the Swedish Energy Agency.

Availability of data and materials

The datasets supporting the conclusions of this article are included within the article.

\section{Authors' contributions}

The main work (80\%) was done by the first author. The co-author contributed significantly to the 'Introduction' and 'Conclusions' section (20\%). All three authors read and approved the final manuscript.

Ethics approval and consent to participate Not applicable.

Consent for publication

Not applicable.

\section{Competing interests}

The authors declare that they have no competing interests.

\section{Publisher's Note}

Springer Nature remains neutral with regard to jurisdictional claims in published maps and institutional affiliations.

\section{Author details}

${ }^{1}$ Department of Engineering and Chemical Sciences, Karlstad University, Karlstad, Sweden. ${ }^{2}$ IIIEEE, International Institute for Industrial Environmental Economics, Lund University, Lund, Sweden. 
Received: 11 April 2017 Accepted: 4 September 2017 Published online: 02 October 2017

\section{References}

1. Statens Energimyndighet (2015) Energiläget 2015. Statens Energimyndighet, Eskilstuna

2. lea (2014) World energy outlook 2014. International energy agency, Paris

3. Xylia M (2016) Is energy efficiency the forgotten key to successful energy policy? Investigating the Swedish case. KTH Royal Institute of Technology, Stockholm

4. Sweco (2014) Styrmedels förutsättningar att styra mot ökad energieffektivisering - en utvärdering av 24 styrmedel. Näringsdepartementet, Stockholm

5. Mahapatra K, Nair G, Gustavsson L (2011) Swedish energy advisers' perceptions regarding and suggestions for fulfilling homeowner expectations. Special Section: Renewable energy policy and development 39:4264-4273. doi:10.1016/j.enpol.2011.04.043

6. Mahapatra K, Nair G, Gustavsson L (2011) Energy advice service as perceived by Swedish homeowners. Int J Consum Stud 35:104-111

7. Statistiska Centralbyrån (Scb) (2015) Allmänhetens energieffektivisering och kännedom om energi- och klimatrådgivare. Statistiska centralbyrån, Stockholm http://www.energimyndigheten.se/globalassets/energieffektivisering/ program-och-uppdrag/ekr/bilaga2-scb.pdf. Accessed 5 Jan 2017

8. Swedish Energy Agency (2015) Översyn av den kommunala energi- och klimatrådgivning In, Eskilstuna

9. Bornehag C-G, Sundell J, Hägerhed-Engman L et al (2005) Association between ventilation rates in 390 Swedish homes and allergic symptoms in children. Indoor Air 15:275-280. doi:10.1111/j.1600-0668.2005.00372.x

10. Kjeang AE (1989) God energirådgivning på 90-talet. Föreningen Sveriges energirådgivare, Stockholm

11. Darby S (1999) Energy advice-what is it worth. Paper presented at the European Council for an Energy-Efficient Economy Summer Study. http:// smartenergydemand.eu/wp-content/uploads/2011/05/Darby-Energy-AdviceWhats-lt-Worth-1999.pdf. Accessed 13 Nov 2016

12. Khan J (2006) Evaluation of the local energy advice programme in Sweden. Lund University, Lund

13. Kjeang AE (2005) Goda energiråd och effektiv användning. Chalmers, Göteborg

14. Lindblom J, Lundström C (2014) Lantbrukares beslutsfattande och lantbruksrådgivning: en förstudie (DEMIPROF). Sveriges Lantbruksuniversitet, Ultuna

15. Ford R, Sumavsk O, Clarke A et al., (2014) Personalized energy priorities: a user-centric application for energy advice. In: Marcus A (ed) Design, User Experience, and Usability. User Experience Design for Everyday Life Applications and Services. Lecture Notes in Computer Science, vol 8519. Springer, Cham

16. Salo M, Nissinen A, Lilja R et al (2016) Tailored advice and services to enhance sustainable household consumption in Finland. J Clean Prod 121: 200-207. doi:10.1016/j.jclepro.2016.01.092

17. Palm J (2010) The public-private divide in household behavior: how far into home can energy guidance reach? Energ Policy 38:2858-2864. doi:10.1016/j. enpol.2010.01.018

18. Palm J (2013) The building process of single-family houses and the embeddedness (or disembeddedness) of energy. Energ Policy 62:762-767. doi:10.1016/j.enpol.2013.08.018

19. Allcott H (2011) Social norms and energy conservation. J Public Econ 95: 1082-1095. doi:10.1016/j.jpubeco.2011.03.003

20. Darby S (2006) The effectiveness of feedback on energy consumption: a review for DEFRA of the literature on metering, billing and direct displays. Environmental Change Institute, University of Oxford, Oxford http://www. eci.ox.ac.uk/research/energy/downloads/smart-metering-report.pdf. Accessed 1 Nov 2016

21. Henryson J, Håkansson T, Pyrko J (2000) Energy efficiency in buildings through information-Swedish perspective. Energ Policy 28:169-180. doi:10.1016/s0301-4215(00)00004-5

22. Hargreaves T, Nye M, Burgess J (2013) Keeping energy visible? Exploring how householders interact with feedback from smart energy monitors in the longer term. Energ Policy 52:126-134. doi:10.1016/j.enpol.2012.03.027

23. Buchanan $K$, Russo R, Anderson B (2015) The question of energy reduction: the problem (s) with feedback. Energ Policy 77:89-96. doi:10.1016/j.enpol. 2014.12.008

24. Ellegård K, Palm J (2011) Visualizing energy consumption activities as a tool for making everyday life more sustainable. Appl Energy 88:1920-1926. doi:10.1016/j.apenergy.2010.11.019
25. Burchell K, Rettie R, Roberts TC (2016) Householder engagement with energy consumption feedback: the role of community action and communications. Energ Policy 88:178-186. doi:10.1016/j.enpol. 2015.10.019

26. Carlsson-Kanyama A, Lindén A-L (2007) Energy efficiency in residences - challenges for women and men in the north. Energ Policy 35: 2163-2172. doi:10.1016/j.enpol.2006.06.018

27. Apajalahti E-L, Lovio R, Heiskanen E (2015) From demand side management (DSM) to energy efficiency services: a Finnish case study. Energ Policy 81: 76-85. doi:10.1016/j.enpol.2015.02.013

28. Pyrko J, Darby S (2011) Conditions of energy efficient behaviour: a comparative study between Sweden and the UK. Energy Efficiency 4:393-408. doi:10.1007/s12053-010-9099-x

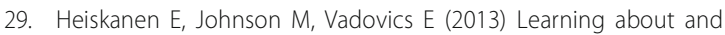
involving users in energy saving on the local level. Environmental Management for Sustainable Universities (EMSU) 2010 European Roundtable of Sustainable Consumption and Production (ERSCP) 2010 48:241-249. doi:10.1016/j.jclepro.2012.08.019

30. Goldbach K, Gölz S (2015) Shaping new opportunities for smart energy efficiency services by engaging users. Paper presented at the 10th Conference on Sustainable Development of Energy, Water and Environment Systems, Dubrovnik, 1st October 2015. https://www.researchgate.net/profile/ Kristin_Goldbach/publication/282646573_Shaping_new_opportunities_for_ smart_energy_efficiency_services_by_engaging_users/links/ 56151cbe08aec622441198ce.pdf. Accessed 1 Nov 2016

31. Revell KMA, Stanton NA (2017) When energy saving advice leads to more, rather than less, consumption. Int J Sustainable Energy 36:1-19. doi:10.1080/ 14786451.2014 .999071

32. Kraidy MM (2002) The Internet as a mass communication medium. J Mass Commun 2:1-23

33. Eurostat Statistics Explained (2016) Digital economy and society statistics - households and individuals http://ec.europa.eu/eurostat/statisticsexplained/index.php?title=Information_society_statistics_-_households_ and individuals\&oldid=285265. Accessed 13 Nov 2016

34. World Bank (2016) Internet users per 100 people http://data.worldbank.org/ indicator/IT.NET.USER.P2. Accessed 1 Nov 2016

35. Takieddine S, Sun J (2015) Internet banking diffusion: a country-level analysis. Electron Commer Res Appl 14:361-371. doi:10.1016/j.elerap. 2015.06.001

36. Railiene $\mathrm{G}$ (2015) E-finance innovations through social activities: the case of Lithuanian banking services. Int J Bus Excell 8:417-432. doi:10.1504/IJBEX. 2015.070313

37. Westelius A (2008) Energirådgivning 2.0-läge och möjligheter. http://www. ep.liu.se/ea/cis/2008/001/cis08001b.pdf. Accessed 1 Sept 2016

38. Pacific Websites (2017) How long listed Google http://www.pacificwebsites. com/about/how-long-listed-google.htm. Accessed 24 Aug 2017

39. Larsson A (2016) Läkare varnar: Ge inte barn LCHF-diet http://sverigesradio. se/sida/artikel.aspx?programid=83\&artikel=6404797. Accessed 6 Apr 2016

40. Novikova A, Amecke $H$, Neuhoff $K$ et al (2011) Information tools for energy demand reduction in existing residential buildings: CPI report. Lund University, Lund

41. Stern PC (1992) What psychology knows about energy conservation. Am Psychol 47:1224. doi:10.1037//0003-066x.47.10.1224

42. Steinhorst J, Matthies E (2016) Monetary or environmental appeals for saving electricity? - potentials for spillover on low carbon policy acceptability. Energ Policy 93:335-344. doi:10.1016/j.enpol.2016.03.020

43. Cialdini RB (2006) Influence - the psychology of persuasion. Harper, New York

44. Gladwell M (2000) The tipping point. How litte things can make a big difference. BlackBay Books, New York

45. Steg L (2008) Promoting household energy conservation. Energ Policy 36: 4449-4453. doi:10.1016/j.enpol.2008.09.027

46. Van Der Werff E, Steg L, Keizer K (2013) It is a moral issue: the relationship between environmental self-identity, obligation-based intrinsic motivation and pro-environmental behaviour. Glob Environ Chang 23:1258-1265. doi:10.1016/j.gloenvcha.2013.07.018

47. Achtnicht M (2011) Do environmental benefits matter? Evidence from a choice experiment among house owners in Germany. Ecol Econ 70:21912200. doi:10.1016/j.ecolecon.2011.06.026

48. Brundtland GH, Khalid M (1991) Our common future. In: Tolba MK, Biswas AK (eds) Earth and us: population resources, environment, development. Butterworth-Heinmann, Oxford 
49. Wibeck V (2014) Enhancing learning, communication and public engagement about climate change: some lessons from recent literature. Environ Educ Res 20:387-411. doi:10.1080/13504622.2013.812720

50. Bdew: Energie. Wasser. Leben Energiewende weiterhin Top-Thema für die Bevölkerung. https://www.bdew.de/internet.nsf/id/20160503-pienergiewende-weiterhin-top-thema-fuer-die-bevoelkerung-de. Accessed 18 Nov 2016

\section{Submit your manuscript to a SpringerOpen ${ }^{\bullet}$ journal and benefit from:}

- Convenient online submission

- Rigorous peer review

- Open access: articles freely available online

- High visibility within the field

- Retaining the copyright to your article

Submit your next manuscript at $\gg$ springeropen.com 